\title{
Low below-ground organic carbon storage in a subarctic Alpine permafrost environment
}

\author{
M. Fuchs ${ }^{1}{ }^{*}$, P. Kuhry ${ }^{1}$, and G. Hugelius ${ }^{1}$ \\ ${ }^{1}$ Department of Physical Geography, Stockholm University, 10691 Stockholm, Sweden \\ *now at: Alfred Wegener Institute Helmholtz Centre for Polar and Marine Research, Telegrafenberg A43, \\ 14473 Potsdam, Germany \\ Correspondence to: M. Fuchs (matthias.fuchs@awi.de)
}

Received: 11 April 2014 - Published in The Cryosphere Discuss.: 1 July 2014

Revised: 22 October 2014 - Accepted: 19 January 2015 - Published: 2 March 2015

\begin{abstract}
This study investigates the soil organic carbon (SOC) storage in Tarfala Valley, northern Sweden. Field inventories, upscaled based on land cover, show that this alpine permafrost environment does not store large amounts of SOC, with an estimate mean of $0.9 \pm 0.2 \mathrm{~kg} \mathrm{C} \mathrm{m}^{-2}$ for the upper meter of soil. This is 1 to 2 orders of magnitude lower than what has been reported for lowland permafrost terrain. The SOC storage varies for different land cover classes and ranges from $0.05 \mathrm{~kg} \mathrm{C} \mathrm{m}^{-2}$ for stone-dominated to $8.4 \mathrm{~kg} \mathrm{C} \mathrm{m}^{-2}$ for grass-dominated areas. No signs of organic matter burial through cryoturbation or slope processes were found, and radiocarbon-dated SOC is generally of recent origin $(<2000$ cal yr BP). An inventory of permafrost distribution in Tarfala Valley, based on the bottom temperature of snow measurements and a logistic regression model, showed that at an altitude where permafrost is probable the SOC storage is very low. In the high-altitude permafrost zones (above $1500 \mathrm{~m}$ ), soils store only ca. $0.1 \mathrm{~kg} \mathrm{C} \mathrm{m}^{-2}$. Under future climate warming, an upward shift of vegetation zones may lead to a net ecosystem $\mathrm{C}$ uptake from increased biomass and soil development. As a consequence, alpine permafrost environments could act as a net carbon sink in the future, as there is no loss of older or deeper SOC from thawing permafrost.
\end{abstract}

\section{Introduction}

The permafrost-affected soil area in the northern circumpolar region is widespread, occupying about 17.8 million $\mathrm{km}^{2}$ (Hugelius et al., 2014). The soils in the northern permafrost region store large amounts of soil organic carbon (SOC), which are vulnerable to climate change. With a warming climate, which is expected to be most pronounced in northern high latitudes, thawing permafrost soils may cause remobilization of soil organic matter (SOM) previously protected in permafrost (Gruber et al., 2004; Schuur et al., 2008). This can lead to an increased microbial decomposition of SOM and a release of carbon dioxide $\left(\mathrm{CO}_{2}\right)$ and methane $\left(\mathrm{CH}_{4}\right)$ into the atmosphere. As a consequence, permafrost soils may act as a future carbon (C) source and lead to a positive climate feedback. However, the total storage of SOC within the northern permafrost region and the amount of greenhouse gases that can be released into the atmosphere and trigger accelerated climate warming are still uncertain (Schuur et al., 2009, 2013; Kuhry et al., 2010; McGuire et al., 2010).

Several local-to-regional-scale studies have been carried out to investigate stocks of SOC in northern permafrost environments (e.g., Michaelson et al., 1996; Kuhry et al., 2002; Zimov et al., 2006a; Ping et al., 2008; Horwath Burnham and Sletten, 2010; Hugelius et al., 2010, 2011). Based on the Northern Circumpolar Soil Carbon Database (NCSCD), Hugelius et al. (2014) estimated the 0-300 cm SOC stock in the northern permafrost region to be $1035 \pm 150 \mathrm{PgC}$ ( $\pm 95 \%$ confidence interval). However, many regions in the NCSCD are underrepresented and contain few sampled pedons, leading to a more generalized estimation of the $\mathrm{C}$ stocks for some remote areas (Mishra et al., 2013). Especially in regions of thin sedimentary overburden, including highlands and alpine terrain, estimates are based on limited data and associated with wide uncertainty ranges (Hugelius et al., 2014). 


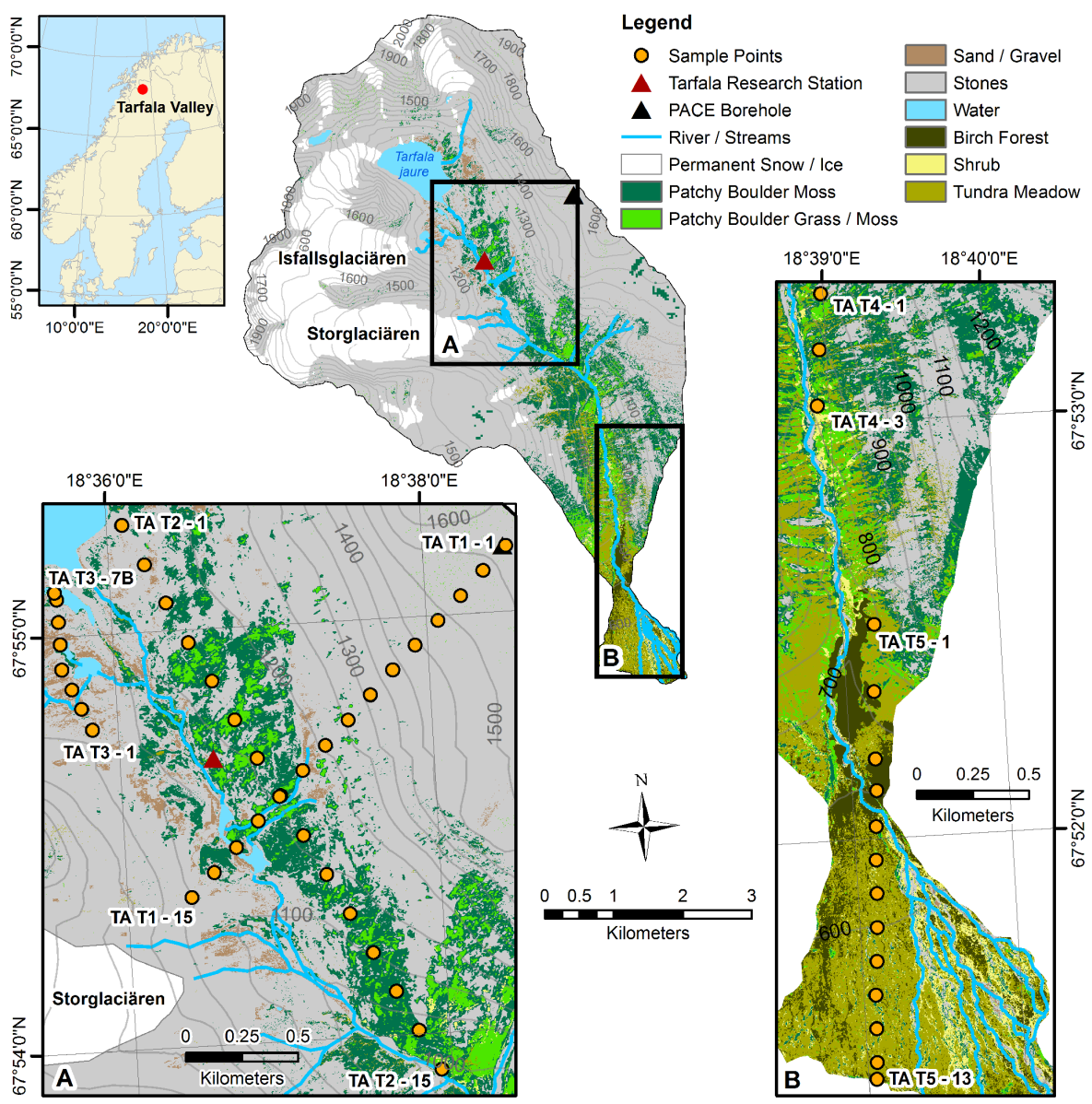

Figure 1. The Tarfala Valley study area, including an overview location map, a map of the whole study area with land cover classification and detailed maps showing transect and sample point locations in the central (a) and lower (b) parts of the valley.

This study presents a detailed SOC inventory for a subarctic alpine permafrost environment by investigating the C stocks in soils of Tarfala Valley, northern Sweden. It is essential to establish to what extent these type of environments contribute to the large SOC storage in the northern permafrost region. Mountain areas and alpine permafrost are sensitive to climate change due to steep ecoclimatic gradients. The aim of this study is to assess the permafrost extent and SOC pools in a subarctic alpine environment and evaluate their potential fate under conditions of future global warming.

\section{Study area}

Tarfala Valley is located in the Scandes mountains of northern Sweden, at ca. $67^{\circ} 55^{\prime} \mathrm{N}, 18^{\circ} 37^{\prime} \mathrm{E}$. The study area $\left(31.2 \mathrm{~km}^{2}\right)$ is delineated based on the catchment of Tarfala River (Tarfalajåkk), which drains into the broader Ladtjovagge. It includes the alluvial fan of Tarfala River to encompass the entire altitudinal gradient from the source to the outlet of Tarfala River. The area ranges between 550 and $2100 \mathrm{~m}$ a.p.s.l. (above present sea level) and is characterized in the upper part by six glaciers that drain into Tarfala River (Fig. 1).

The mean annual air temperature (MAAT) at the Tarfala research station is $-3.4^{\circ} \mathrm{C}(1965-2009)$ and the mean annual precipitation for the Tarfala River catchment is $1997 \mathrm{~mm}$ (Dahlke et al., 2012). The MAAT in Tarfala increased by $0.54{ }^{\circ} \mathrm{C}$ per decade for the period $1969-2009$, whereas the mean annual precipitation did not change significantly (Dahlke et al., 2012). The mean altitudinal lapse rate between the Tarfala research station (1135 ma.p.s.l.) and the mountain saddle (Tarfalaryggen) along the eastern border of the study area (1540 m a.p.s.l.) is ca. $4.5^{\circ} \mathrm{C} \mathrm{km}^{-1}$; however, the lapse rate in the summer months (JJA) of around $5.8^{\circ} \mathrm{C} \mathrm{km}^{-1}$ is significantly higher than the winter (DJF) lapse rate of around $2.7^{\circ} \mathrm{C} \mathrm{km}^{-1}$ (Jonsell et al., 2013).

The vegetation cover in the study area is generally sparse. In high-elevation areas there is mostly barren ground. The middle part of the valley, around the Tarfala research station (1135 ma.p.s.l.), is characterized by patchy boulder fields 
and shallow soils with a mix of bare rocks, grasses, mosses and lichen. Further down the valley, dwarf shrubs (mainly Salix species and Empetrum hermaphroditum) appear up to $1000 \mathrm{~m}$ a.p.s.l. and the mountain birch forest (Betula pubescens ssp. czerepanovii) reaches up to ca. $750 \mathrm{~m}$ a.p.s.1. On the alluvial fan, in the lowest part of the study area, the vegetation consists of a mix of deciduous and evergreen shrubs, graminoids and herbs.

Tarfala Valley is characterized by little and very shallow soil development. The predominant soils in the study area are characterized by very limited soil formation with poorly developed soil genetic horizons, high stone content and shallow regolith. These soils are classified as Leptosols and Regosols (IUSS Working Group WRB, 2006). On Tarfalaryggen, soil movement caused by frost-thaw cycles (cryoturbation) has led to patterned ground formation, and there is permafrost in the upper $2 \mathrm{~m}$ of soil; these soils are classified as Turbic Cryosols. In riverbed deposits of glacial streams (e.g., in the glacier forefield of Isfallsglaciären), soils are classified as Fluvisols.

Extensive research has been carried out in Tarfala Valley, focusing mainly on glaciology and permafrost. Glaciers are the main subject of studies, with Storglaciären having the longest ongoing glacier mass balance measurements in the world (Holmlund et al., 2005). According to Brown et al. (1997), Tarfala Valley is located in the discontinuous permafrost zone. A permafrost borehole installed by the PACE (Permafrost and Climate in Europe) project is situated $1540 \mathrm{~m}$ a.p.s.l. on Tarfalaryggen (Harris et al., 2001). The borehole measures the soil temperature down to $100 \mathrm{~m}$ every $6 \mathrm{~h}$ (Sollid et al., 2000). Mean annual ground temperature at the depth of zero annual amplitude is $-2.8^{\circ} \mathrm{C}$, with a mean active layer depth of $1.5-1.6 \mathrm{~m}$. Permafrost is currently not present in a $15 \mathrm{~m}$ deep borehole located at an elevation of $1135 \mathrm{~m}$ a.p.s.l. near Tarfala research station (Bolin Centre for Climate Research, 2013). King (1984) reports an active layer depth of $2.5-4 \mathrm{~m}$ in the valley floor around $1200 \mathrm{~m}$ a.p.s.l.

Even though many scientific studies have been carried out in Tarfala Valley (e.g., Stork, 1963, on vegetation cover; King, 1984, and Isaksen et al., 2007, on permafrost; Holmlund et al., 2005, and Jansson and Pettersson, 2007, on glaciology; Dahlke et al., 2012, on hydrology), there are no previous studies on SOC storage from this area.

\section{Methods}

\subsection{Soil sampling}

In August 2012, a stratified random sampling program was executed in Tarfala Valley, during which soil profiles were collected along five transects. Transects were chosen to represent the altitudinal zones and vegetation types in the valley. Strict equidistant individual profiles were placed along the transects to introduce a degree of randomness in the sam- pling. Near-surface organic layers were collected from pits dug into the soils by cutting out samples of known volume. Deeper soil layers were sampled by hammering a steel pipe of ca. $4 \mathrm{~cm}$ diameter into the soil vertically in $5-10 \mathrm{~cm}$ depth increments. Coring was pursued so that the whole profile was collected to a depth of $1 \mathrm{~m}$, if possible. Most of the collected soil profiles were shallow because the stony soils did in no single case enable a sampling to the full reference depth of $100 \mathrm{~cm}$. The soil was mostly of uniform nature and, during collection of soil samples, no indication of soil organic matter buried through cryoturbation could visually be detected. Furthermore, permafrost was never encountered during coring, even at high elevations, indicating generally deep active layers in Tarfala Valley. In total, 56 profile sites were sampled and described and 295 individual soil samples collected.

\subsection{Land cover classification}

A description of the vegetation cover in a ground-truth plot (diameter $10 \mathrm{~m}$ ) was made around each profile site, with special attention paid to the occurrence of stones and boulders (see description of SOC mass calculation below). For upscaling purposes, a land cover classification (LCC) was compiled from remotely sensed data. For this LCC, an orthophoto (compiled with ERDAS Imagine LPS from CIR aerial photographs with $0.5 \mathrm{~m}$ spatial resolution) (Lantmäteriet, 2008), a WorldView2 satellite image (European Space Imaging GMBH, 2012) and a Landsat 5 (TM) (US Geological Survey, 2011) satellite image were used. The remote mountainous area as well as cloud and snow cover in the images made a usage of different data sets unavoidable to cover the whole valley. The LCC includes nine different classes which have been separated by a combination of a 3-D stereo analysis and supervised classification (maximum likelihood). The requirements for a supervised classification in general and the training areas in particular followed Campbell (2011). To verify the classification, the kappa index of agreement was calculated based on the 56 ground-truth plots. Nine dominant land cover classes were recognized in Tarfala Valley and form the basis for establishing a land cover classification based on field and remotely sensed data. The classes are presented in the Supplement (Table S1).

\subsection{Geochemical analyses}

Soil samples of known volume were weighed in the laboratory after oven drying at $60^{\circ} \mathrm{C}$ (for $48 \mathrm{~h}$ ) to calculate dry bulk density (DBD, $\mathrm{g} \mathrm{cm}^{-3}$ ). For loss on ignition (LOI), samples were burned at $550^{\circ} \mathrm{C}$ for $6 \mathrm{~h}$ to determine the organic carbon content and at $950^{\circ} \mathrm{C}$ for $2 \mathrm{~h}$ to determine the carbonate content (Dean, 1974; Heiri et al., 2001). In addition, a subset of 96 samples was further homogenized, freeze-dried and analyzed, first with a CarloErba NC 2500 elemental analyzer to determine $\mathrm{C} / \mathrm{N}$ (weight) ratios and second with a coupled mass spectrometer (Finnigan DeltaV Advantage) to 
determine the stable isotope composition of $\delta^{13} \mathrm{C}$ and $\delta^{15} \mathrm{~N}$. Four bulk soil samples were submitted to the Radiocarbon Laboratory in Poznan, Poland, for dating with the accelerator mass spectrometry (AMS) approach (Walker, 2005). After the analysis, radiocarbon dates were calibrated into calendar years, cal yr BP (1950), and expressed as the mean age of the highest $68 \%$ probability interval using the software OxCal 4.1.7 (Bronk Ramsey, 2010).

\subsection{SOC storage calculations}

The organic $\mathrm{C}$ values obtained from the elemental analysis for 96 samples were used to estimate the $\mathrm{C}$ percentage (C \%) of the remaining 199 samples for which only LOI results were available. Rather than using a constant conversion factor, this is based on a third order polynomial regression between the $\mathrm{C} \%$ and LOI for those samples where both parameters were measured $\left(n=96, r^{2}=0.95\right)$ :

$$
\begin{aligned}
\mathrm{C}(\%) & =0.000004 \cdot\left(\mathrm{LOI}_{550}\right)^{3}-0.000352 \cdot\left(\mathrm{LOI}_{550}\right)^{2} \\
& +0.481602 \cdot\left(\mathrm{LOI}_{550}\right) .
\end{aligned}
$$

SOC mass $\left(\mathrm{kg} \mathrm{C} \mathrm{m}^{-2}\right)$ was calculated for each sample with the $\operatorname{DBD}\left(\mathrm{g} \mathrm{cm}^{-3}\right)$, the percentage organic $\mathrm{C}$, the coarse fragment fraction $(>2 \mathrm{~mm})(\mathrm{CF}, \%)$ and the sample depth interval with the following equation:

$\operatorname{SOC}\left(\mathrm{kgCm}^{-2}\right)=\mathrm{DBD} \cdot C \cdot(1-\mathrm{CF}) \cdot \operatorname{depth} \cdot 10$.

The SOC storage $\left(\mathrm{kg} \mathrm{C} \mathrm{m}^{-2}\right)$ in each soil profile was calculated by adding up the SOC mass of all samples $(5-10 \mathrm{~cm}$ depth increments) for the reference depths of $0-30$ and 0$100 \mathrm{~cm}$. It should be noted, however, that in all cases it was not possible to reach a full depth of $100 \mathrm{~cm}$ due to the occurrence of large stones, boulders or bedrock (these are assumed to contain no SOC). Storage was calculated separately for the organic-rich top soil layer and the underlying mineral soil layer. The division between these layers was made based on field observations. The mean SOC storage for each of the recognized land cover types is calculated as the arithmetic mean of all soil profiles representing those land cover types. To avoid overestimation of the C content, each LCC mean SOC $\mathrm{kg} \mathrm{C} \mathrm{m}^{-2}$ value was weighted by the mean percentage of large stones ( $>4 \mathrm{~cm}$ diameter) visible at the surface. These areas were considered to have no soil development and to contain no SOC. The coverage of large stones was derived by field observations at every sample spot within a radius of $5 \mathrm{~m}$. Thereafter, the mean SOC storage in Tarfala Valley was calculated based on the proportions of the land cover classes in the LCC. These calculations were performed for all land cover classes together (including glaciers, barren grounds and lakes) and for the vegetated classes only.

\subsection{Statistical methods}

The results from the geochemical analyses and the upscaling were further analyzed with statistical methods. All statistical analyses were carried out with the open-source statistical analysis package PAST 2.17 (Hammer et al., 2001). Three main statistical analyses were carried out: (1) confidence intervals (CI) for the mean $\mathrm{C}$ estimates of the total study area were calculated according to Hugelius (2012); (2) linear correlations (Pearson's correlation) between soil depth and the different geochemical parameters (DBD, C \%, LOI, C/Nratio, $\delta^{13} \mathrm{C}, \delta^{15} \mathrm{~N}$ ) were calculated to examine whether the different parameters decrease or increase significantly with increasing depth; (3) the Student's $t$ test was applied to examine if there is a statistically significant difference between the organic-rich top soil and the underlying mineral samples for all the different geochemical parameters. In all cases, the probability limit of $p \leq 0.01$ was chosen for statistical significance.

\subsection{Permafrost mapping}

In addition to the SOC inventory, the permafrost distribution in Tarfala Valley was mapped. Bottom temperature of snow (BTS) measurements were carried out in March 2013, with the precision temperature-measuring instrument, Series P400 (Dostmann Electronic, 2013). This handheld thermometer has an accuracy of $\pm 0.3^{\circ} \mathrm{C}$ and a resolution of $0.1^{\circ} \mathrm{C}$. The temperature probe was calibrated in ice water to $0^{\circ} \mathrm{C}$ before every field day. The BTS method is a simple and costeffective approach to get a first impression on the distribution of permafrost by measuring the temperature at the snowground surface interface. For this method a snow cover of a minimum of $80 \mathrm{~cm}$ is required to provide sufficient insulation from variable air temperatures above the snow pack (Haeberli, 1973; King, 1983). With the BTS values, a logistic regression with altitude as the single independent variable was used to map the probability of permafrost occurrence. For the logistic regression, BTS values were classified into permafrost likely and non-permafrost likely. The threshold values for permafrost-likely BTS values vary dependent on snow depth and range from -2.5 to $-4.5^{\circ} \mathrm{C}$ (King, 1984). Altitude was chosen as single independent variable because other possibly important parameters for permafrost occurrence (slope, aspect, solar radiation, etc.) showed no significant correlation with measured BTS values. Using the permafrost probability map, the amount of SOC stored in probable permafrost areas could be estimated.

\section{Results}

\subsection{Land cover classification}

The LCC presented in Fig. 1 has an overall accuracy of $72.2 \%$ and a kappa index of agreement of 0.68 . The rather 
low kappa index can be explained by snow cover at higher elevations in the orthophoto, which needed to be corrected by a Landsat 5 (TM) image with a coarser spatial resolution. The LCC shows that Tarfala Valley is dominated by rocks and stones that cover almost $60 \%$ of the area and permanent snow and ice that cover more than $18 \%$. The largest vegetated land cover class is "patchy boulder moss" which covers almost $10 \%$ of the landscape, but this class is defined as a mix of moss and stones that on average has more than $40 \%$ stones. All land cover classes include a certain amount of stones, which ranges from $4 \%$ in the class "birch forest" to $47 \%$ in the class "sand/gravel" (for more details, see Table S1).

\subsection{SOC quantity}

The mean SOC storage of the study area including all land cover classes is $0.7 \pm 0.2$ and $0.9 \pm 0.2 \mathrm{~kg} \mathrm{C} \mathrm{m}^{-2}$ for 0 30 and $0-100 \mathrm{~cm}$ soil depths, respectively (mean $\pm 95 \% \mathrm{CI}$ ) (Table 1). Calculations have also been made for the vegetated area only. This area excludes the low SOC land cover classes "stone", "sand/gravel", "water" and "permanent snow/ice" and, therefore, the mean $\mathrm{C}$ storage is considerably higher than for the entire study area. The mean SOC for the vegetated area only is $3.7 \pm 0.8$ and $4.6 \pm 1.2 \mathrm{~kg} \mathrm{C} \mathrm{m}^{-2}$ for 0 30 and $0-100 \mathrm{~cm}$ soil depths, respectively (mean $\pm 95 \% \mathrm{CI}$ ).

A detailed analysis of the different land cover classes shows the partitioning of $\mathrm{C}$ stored in Tarfala (Fig. 2). Most of the SOC in Tarfala Valley is stored in the class "tundra meadow" ( $35 \%$ of SOC) even though it only covers $4.3 \%$ of the total study area. However, the highest mean value occurs in the class "patchy boulder grass/moss", which stores on average $8.4 \pm 5.4 \mathrm{~kg} \mathrm{C} \mathrm{m}^{-2}$ (Table 1) and accounts for $24 \%$ of the total SOC storage in Tarfala Valley.

The coefficient of variation of the mean SOC values of the land cover classes is high (near 1 in many cases), which is an effect of the high within-class variability in depth of the finegrained deposits overlying coarse regolith or bedrock (also reflected in the standard deviation of the mean profile depth, see Table 1). Therefore the variability of profile depth within the different land cover classes is reflected in the variability of organic carbon for single classes. Additionally, the coarse fragment fraction $(>2 \mathrm{~mm}$ ) varied within classes (data not shown). Besides the variability in fine-soil depth, the results show that most of the organic $\mathrm{C}$ is stored in near-surface layers. On average, more than $80 \%$ of the SOC is stored within the upper $30 \mathrm{~cm}$ of soil and a third of the SOC is stored in the organic-rich top soil layer. This also allows an estimation of the SOC stored within the permafrost layer. As the active layer in Tarfala Valley seems to be on the order of 1.5-4 m thick (King, 1984; Isaksen et al., 2007), it can be assumed that only a very minor-to-negligible amount of organic $\mathrm{C}$ is stored within the permafrost layer. It should be noted that permafrost was never reached during field coring due to the occurrence of bare rock and stones.

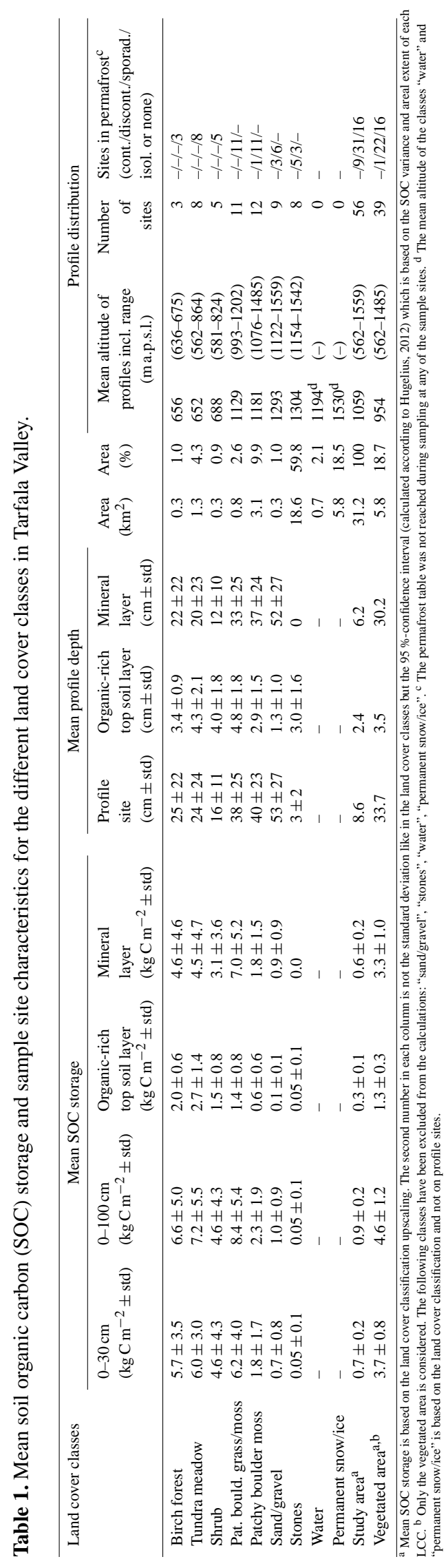

The Cryosphere, 9, 427-438, 2015 
Table 2. Statistics of the geochemical analyses of soil samples.

\begin{tabular}{lccccc}
\hline $\begin{array}{l}\text { Geochemical } \\
\text { analysis }\end{array}$ & $\begin{array}{c}\text { All } \\
\text { samples, } \\
\text { mean } \pm \text { std }\end{array}$ & $\begin{array}{c}\text { Organic-rich } \\
\text { top soil layer } \\
\text { samples, } \\
\text { mean } \pm \text { std }\end{array}$ & $\begin{array}{c}\text { Mineral layer } \\
\text { samples, } \\
\text { mean } \pm \text { std }\end{array}$ & $\begin{array}{c}\text { Significant difference } \\
\text { between organic and } \\
\text { mineral samples, } \\
\text { Student's } t \text { test }\end{array}$ & $\begin{array}{c}\text { Correlation with } \\
\text { increasing depth, } \\
\text { Pearson's } \\
\text { correlation }\end{array}$ \\
\hline DBD $\left(\mathrm{g} \mathrm{cm}^{-3}\right)^{*}$ & $0.9 \pm 0.8$ & $0.4 \pm 0.3$ & $1.6 \pm 0.7$ & yes $(p<0.01)$ & $0.71(p<0.01)$ \\
COI $_{550}(\%)^{*}$ & $21.6 \pm 27.0$ & $40.3 \pm 28.5$ & $4.8 \pm 8.1$ & yes $(p<0.01)$ & $-0.47(p<0.01)$ \\
LOI $_{950}(\%)^{*}$ & $0.4 \pm 0.4$ & $0.4 \pm 0.4$ & $0.3 \pm 0.4$ & no $(p=0.06)$ & $-0.11(p=0.05)$ \\
$\% \mathrm{C}$ & $11.4 \pm 13.8$ & $25.8 \pm 13.7$ & $3.8 \pm 5.2$ & yes $(p<0.01)$ & $-0.54(p<0.01)$ \\
$\mathrm{C} / \mathrm{N}$ ratio (-) & $17.6 \pm 8.5$ & $23.3 \pm 11.4$ & $14.6 \pm 4.1$ & yes $(p<0.01)$ & $-0.38(p<0.01)$ \\
$\delta^{13} \mathrm{C}_{\text {tot }}$ vs. PDB (\%o) & $-26.1 \pm 1.2$ & $-26.8 \pm 1.0$ & $-25.6 \pm 1.0$ & yes $(p<0.01)$ & $0.42(p<0.01)$ \\
$\delta^{15} \mathrm{~N}$ vs. air (\%o) & $1.8 \pm 2.6$ & $-0.54 \pm 2.0$ & $3.2 \pm 1.8$ & yes $(p<0.01)$ & $0.53(p<0.01)$ \\
\hline
\end{tabular}

* Calculations carried out with all 295 samples; other calculations based on 96 samples from elemental analysis.

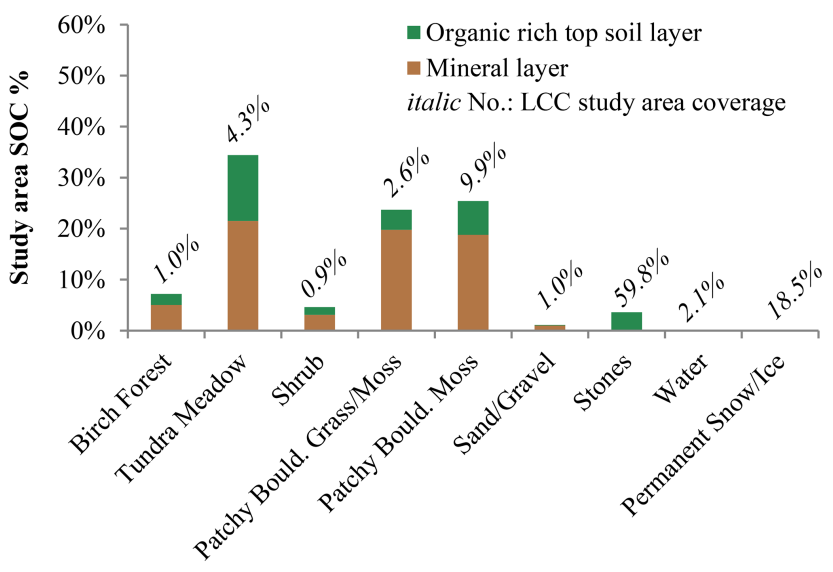

Figure 2. Partitioning of total SOC storage and proportional area coverage of land cover classes in Tarfala Valley $\left(31.2 \mathrm{~km}^{2}\right)$.

The soils of Tarfala Valley display no signs of cryoturbation of the organic-rich top soil layer into the deeper mineral soil horizons. Likewise, no burial of the organic-rich layer due to solifluction processes on slopes was observed.

\subsection{SOM quality and age}

The soils in Tarfala Valley are characterized by a steady, statistically significant $(p<0.01)$ increase in bulk density with depth (Fig. 3a; Table 2). However, LOI $\left(550^{\circ} \mathrm{C}\right)$ and $\mathrm{C} \%$ show strong, statistically significant $(p<0.01)$ negative correlations with depth (Fig. 3b; Table 2). As a result, there is less SOM with greater depth in the soil. There is also a statistically significant ( $t$ test, $p<0.01$ ) difference in the $\mathrm{C}$ content of the organic-rich top soil layer and the underlying mineral layer (Table 2). During field sampling there were no observations of buried SOM through, for example, cryoturbation or solifluction. Similarly, the laboratory results showed no single value or outlier with high $\mathrm{C} \%$ below the top organic layer. Therefore, there are neither visual nor laboratory results indicating burial of organic carbon to depth in the investigated soil profiles.

Besides $\mathrm{C}$ content, other geochemical analyses of the soil samples also show a coherent picture. The $\mathrm{C} / \mathrm{N}$ ratio and stable isotopic composition of SOM reflect its relative state of decomposition (e.g., Mariotti and Balesdent, 1990; Kuhry and Vitt, 1996; Ping et al., 1998; Hugelius et al., 2012). There is a statistically significant $(t$ test, $p<0.01)$ difference between the mean $\mathrm{C} / \mathrm{N}$ ratio of the organic-rich top soil layer $(23.3 \pm 11.4)$ and that of the mineral layer $(14.6 \pm 4.05)$. The $\mathrm{C} / \mathrm{N}$ ratio decreases with increasing depth $(p<0.01)$, indicating progressively more decomposed SOM (Fig. 3c). Ping et al. (1998) pointed out that the $\mathrm{C} / \mathrm{N}$ ratio is dependent on vegetation cover and that trends need to be interpreted carefully. In Tarfala Valley, the decrease of $\mathrm{C} / \mathrm{N}$ ratio with depth is consistent across all land cover classes. However, these trends are not statistically significant for the separate land cover classes, probably due to the limited number of replicates within each class (data not shown). The stable isotope composition of $\delta^{13} \mathrm{C}$ vs. PDB and $\delta^{15} \mathrm{~N}$ vs. air shows statistical significant $(p<0.01)$ enrichment of stable isotopes with increasing soil depth (Fig. 3d; Table 2). The enrichment of $\delta^{13} \mathrm{C}$ and $\delta^{15} \mathrm{~N}$ with depth can be considered an indication of SOM degradation through microbial respiration (Mariotti and Balesdent, 1990; Ping et al., 1998).

Four bulk soil samples (living roots removed) from two profiles belonging to the class "patchy boulder grass/moss", located close to the floor of the central Tarfala Valley, have been radiocarbon-dated (Table 3). These profiles were selected because they had the thickest organic-rich top soil layer among the collected profiles in the study area and displayed a slight, but highly unusual for this area, C enrichment in the underlying mineral soil (weak B-horizon development). Results indicate that the SOM close to the surface is recent in age $(<100$ years old), whereas the mineral soil at greater depths contains slightly older SOM, with ages of 1269 and 1919 cal yr BP (Table 3). Considering the fact that the two dated profiles are among the most well-developed 
Table 3. Results from the radiocarbon analysis.

\begin{tabular}{lccllr}
\hline Site & $\begin{array}{c}\text { Depth } \\
(\mathrm{cm})\end{array}$ & Lab. no. & Site and sample description & Age ${ }^{14} \mathrm{C}$ & $\begin{array}{r}\text { Age } \\
\text { cal yr BP }\end{array}$ \\
\hline TA T1-9B & $19-20$ & Poz-51853 & Grass/moss patch, base of top organics & $123.48 \pm 0.4$ pMC & modern \\
TA T1-9B & $50-60$ & Poz-51854 & Grass/moss patch, silty sand and stones & $2035 \pm 35$ BP & 1919 \\
TA T2-11 & $10-15$ & Poz-51856 & Grass/moss patch, base of top organics & $95 \pm 30$ BP & 20 \\
TA T2-11 & $33-37$ & Poz-51857 & Grass/moss patch, silty sand and small stones & $1380 \pm 30$ BP & 1269 \\
\hline
\end{tabular}
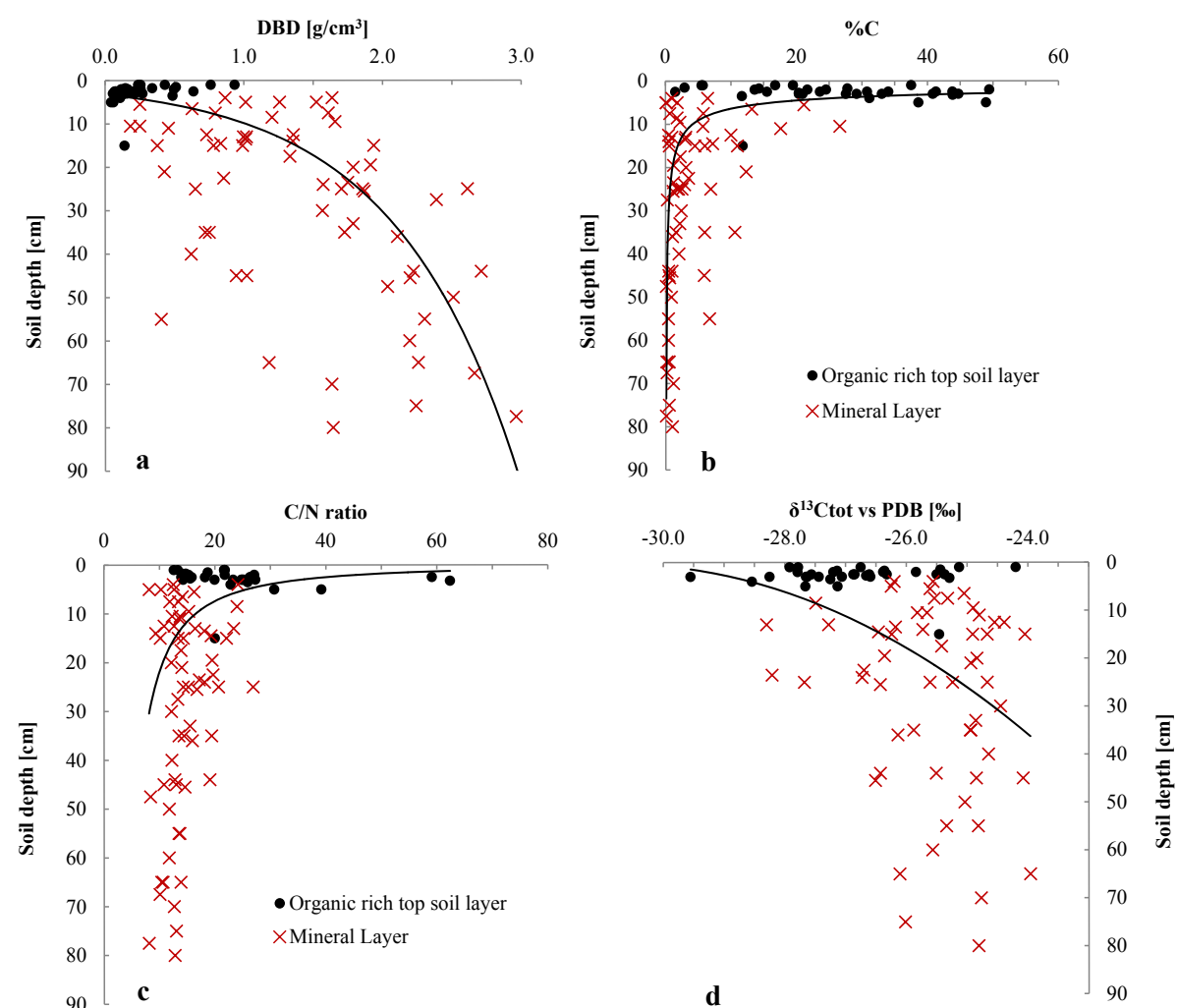

Figure 3. Results of the geochemical analyses of the soils samples of Tarfala Valley. DBD is Dry bulk density (a); \% C is percentage C (b); $\mathrm{C} / \mathrm{N}$ is the weight ratio (c); $\delta^{13} \mathrm{C}_{\text {tot }}$ vs. PDB is the stable isotope $\delta^{13} \mathrm{C}$ analyzed to the international standard PeeDeeBelemnite (d). Lines are best-fit power, polynomial or exponential regressions, shown for graphic representation of mean trends only. Some high bulk density values (up to $3.0 \mathrm{~g} \mathrm{~cm}^{-3}$ ) in sandy profile sites are probably the result of errors in field volume estimates due to difficulties in collecting these loose materials.

soils in the study area, it is most likely that most of the SOM in Tarfala Valley is of a very young age. The geochemistry of these two dated profiles, which reflect the general trends described for the whole data set, is presented in the Supplement (Fig. S2).

\subsection{Permafrost mapping}

Permafrost zones are commonly separated into the classes continuous, discontinuous, sporadic and isolated patches (e.g., Brown et al., 1997). However, with the logistic regression approach the probability for the occurrence, rather than the areal extent, of permafrost was used to map the per- mafrost distribution into the conventional classes (Fig. 4). This was already applied by Lewkowicz and Ednie (2004) in their study in Yukon Territory, Canada. However, with this approach the permafrost distribution has to be interpreted carefully, especially in a highly heterogeneous alpine environment like Tarfala Valley. Areas with a $>90 \%$ probability for the occurrence of permafrost are considered as continuous, which in Tarfala Valley includes all areas above $1561 \mathrm{~m}$ a.p.s.l. The discontinuous permafrost zone (probability between 50 and $90 \%$ ) occurs at an altitude between 1218 and $1561 \mathrm{ma.p.s.l.,}$, while the sporadic permafrost zone commences at an altitude above 875 m a.p.s.l. (probability $>10 \%$ ). The altitudinal zonation 


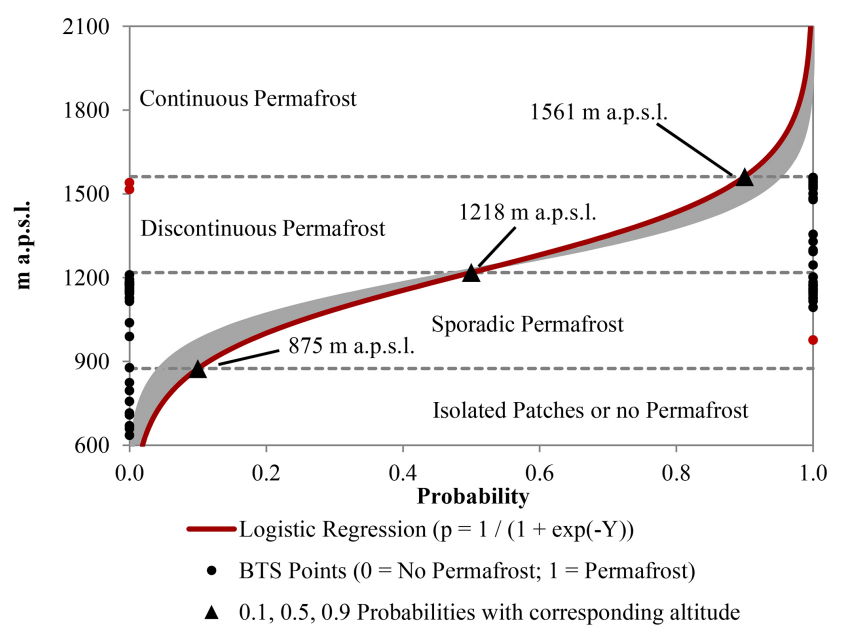

Figure 4. Permafrost probability in relation to altitude: the probability is based on a logistic regression model with the altitude as single independent variable. The grey corridor shows the range of the permafrost probability if outliers (red dots) are removed from the model.

of permafrost as depicted in Fig. 4 is very similar to those proposed by King (1983) and Marklund (2011), particularly if some outliers are removed from our analysis. The lowermost site where BTS values suggest permafrost is located at $976 \mathrm{~m}$ a.p.s.l.; measurements at two high-elevation sites (ca. $1500 \mathrm{~m}$ a.p.s.l.) suggest an absence of permafrost. While there are no technical reasons to reject these results, these outliers should be considered with caution due to the inherently large uncertainty range in the BTS method.

\section{Discussion}

\subsection{Current SOC quantity and SOM composition}

The results presented for Tarfala Valley show very low SOC storage compared to inventories from lowland areas in the northern permafrost region (e.g., Michaelson et al., 1996; Kuhry et al., 2002; Hugelius et al., 2010). However, the mean value of $0.9 \mathrm{~kg} \mathrm{C} \mathrm{m}^{-2}(0-100 \mathrm{~cm})$ is quite close to values reported for other mountainous environments. Kuhry et al. (2002) estimated a mean value of $0.3 \mathrm{~kg} \mathrm{C} \mathrm{m}^{-2}$ for the land cover class "natural barelands" and $1.3 \mathrm{~kg} \mathrm{C} \mathrm{m}^{-2}$ for the land cover class "alpine sparse tundra", which together represent ca. $8 \%$ of the total catchment area of the Usa basin (northeast European Russia); Ping et al. (2008) estimated a value of $3.8 \mathrm{~kg} \mathrm{C} \mathrm{m}^{-2}$ for "mountain soils" in the North American Arctic region. The number of pedons in both these studies is very low ( $n=1$ to 4 ).

Considering values from only the vegetated area in Tarfala Valley, the mean SOC values are $3.7 \mathrm{~kg} \mathrm{C} \mathrm{m}^{-2}$ for $0-30 \mathrm{~cm}$ and $4.6 \mathrm{~kg} \mathrm{C} \mathrm{m}^{-2}$ for $0-100 \mathrm{~cm}$ soil-depth intervals. Similar SOC inventories on vegetated patches have been carried out in the Tibetan plateau. Doerfer et al. (2013) measured the SOC content in the Huashixia and Wudaoliang region, which resulted in mean values of 10.4 and $3.4 \mathrm{~kg} \mathrm{C} \mathrm{m}^{-2}$, respectively, for $0-30 \mathrm{~cm}$. The land cover was in both cases classified as "alpine meadow". Our mean SOC value for the class "tundra meadow" and the corresponding depth interval is $6.0 \mathrm{~kg} \mathrm{C} \mathrm{m}^{-2}$. Other SOC inventories on the Tibetan plateau showed similar results. Ohtsuka et al. (2008) measured a mean SOC content of $1.0-13.7 \mathrm{~kg} \mathrm{C} \mathrm{m}^{-2}$ for $0-30 \mathrm{~cm}$ in "alpine meadow"; Yang et al. (2008) measured $9.6 \mathrm{~kg} \mathrm{C} \mathrm{m}^{-2}$ in "alpine meadow" and $3.1 \mathrm{~kg} \mathrm{C} \mathrm{m}^{-2}$ for "alpine steppe"; and Wang et al. (2008) measured $9.3-10.7 \mathrm{~kg} \mathrm{C} \mathrm{m}^{-2}$ for "alpine grasslands" (our corresponding value for the "patchy boulder grass/moss" class is $6.2 \mathrm{~kg} \mathrm{C} \mathrm{m}^{-2}$ ). A SOC inventory from the Swiss Alps showed higher values than Tarfala Valley. Zollinger et al. (2013) investigated "alpine grassland" (at $2700 \mathrm{~m}$ a.p.s.l.) and "subalpine forest" (at $1800 \mathrm{~m}$ a.p.s.l.) soils and estimated the $\mathrm{C}$ stocks down to the $\mathrm{C}$-horizon at ca. $10 \mathrm{~kg} \mathrm{C} \mathrm{m}^{-2}$ for permafrost and ca. $15 \mathrm{~kg} \mathrm{C} \mathrm{m}^{-2}$ for nonpermafrost sites. It has to be emphasized that these values represent only the mean of the vegetated sites and are not based on a landscape upscaling to include all mountainous terrain. Nonetheless, in all these studies, the high SOC content often reported from lowland permafrost areas, ranging between ca. 25 and $50 \mathrm{~kg} \mathrm{C} \mathrm{m}^{-2}$ (e.g., Michaelson et al., 1996; Kuhry et al., 2002; Hugelius et al., 2010), is never achieved.

Several reasons for the low SOC values in Tarfala Valley seem obvious. There is a high amount of bare ground and glaciated terrain in the study area (almost ca. 80\%) which leads to very limited in situ production of organic plant matter in the system. Even the vegetated classes have abundant stone cover which diminishes the landscape fraction with fine-soil development. The fraction of stone coverage in the different land cover classes varied between 4 and $47 \%$ (the soil volume occupied by stones was considered devoid of SOC in stock calculations). Furthermore, no signs of SOM burial by cryoturbation or solifluction processes were observed in any investigated soil profile. Burial of SOM through cryoturbation or slope processes are important mechanisms explaining high SOC stocks in other permafrost environments (Palmtag et al., 2015). The active layer in Tarfala Valley is significantly deeper than the depth of active soil formation, which means that organic carbon decomposition is not impeded by sub-zero temperatures during the warm season. The steep topography and coarse sediments favor rapid drainage and aerated soils. No peat formation or peaty soils were observed in Tarfala Valley. Finally, the soils are rather shallow; in most cases they do not reach a depth of $1 \mathrm{~m}$ and sometimes not even $30 \mathrm{~cm}$. As a consequence of all these factors, the soils in Tarfala Valley are not characterized by any of the pedogenic processes that often lead to the accumulation of high stocks of SOC in permafrost region soils (Tarnocai et al., 2009). 
The mean value for Tarfala soils down to $1 \mathrm{~m}$ depth $\left(0.9 \mathrm{~kg} \mathrm{C} \mathrm{m}^{-2}\right)$ is considerably lower than the one reported for the Swedish mountains $\left(26.1 \mathrm{~kg} \mathrm{C} \mathrm{m}^{-2}\right)$ in the Northern Circumpolar Soil Carbon Database (Hugelius et al., 2013). The high value in the NCSCD can be explained by the highly generalized soil map on which these estimates are based. The NCSCD soil polygon that overlaps with the Tarfala Valley study area has an area of ca. $2900 \mathrm{~km}^{2}$ and includes adjacent lowland terrain with peatland (Histosols) and forested (Podsols) areas.

Geochemical indicators, such as $\mathrm{C} / \mathrm{N}$ ratios and stable isotopes $\left(\delta^{13} \mathrm{C}\right.$ and $\left.\delta^{15} \mathrm{~N}\right)$, indicate that the SOM in Tarfala soils becomes gradually more decomposed with depth and age. Cryoturbation of C-enriched material is one of the mechanisms that significantly increases SOC storage in permafrost soils (e.g., Ping et al., 2008). In Tarfala we did not find evidence for burial of relatively non-decomposed SOM from the organic-rich top soil layer deeper into the profiles. The two dated soil profiles are exceptional for Tarfala Valley as they have the thickest organic-rich top soil layer and relatively high carbon values in greater depths. However, basal dates for even these thickest organic-rich top soil layers are recent and the SOC at greater depth is also quite young $(<2000$ cal yr BP). Therefore, much of the SOM in Tarfala Valley seems to be cycled within 100 years or less and does not accumulate at greater depths. This is in stark contrast to permafrost soils from lowland regions, which are reported to have extensive cryoturbation of relatively non-decomposed SOM that has been preserved at greater soil depths for thousands of years (e.g., Bockheim, 2007; Hugelius et al., 2010).

\subsection{Future developments}

Our results indicate that there is not a large amount of SOC stored in the soils of Tarfala Valley. The relatively highest mean SOC storage is found in vegetated ground at lower elevations. A further analysis that takes into account the permafrost zonation shows that the potential for SOC storage in permafrost-affected soils is very small (Fig. 5). The mean SOC value at an elevation of $1250 \mathrm{~m}$ a.p.s.l., where the probability for permafrost is just above $50 \%$, is $0.7 \mathrm{~kg} \mathrm{C} \mathrm{m}^{-2}$ (for $0-100 \mathrm{~cm}$ ) and at an altitude of $1500 \mathrm{~m}$ a.p.s.l. (permafrost probability $85 \%$ ) it is only $0.1 \mathrm{~kg} \mathrm{C} \mathrm{m}^{-2}$. Therefore, most of the SOC in Tarfala Valley is stored at lower elevations where the probability for permafrost-affected soils is low. Taking into account that the active layer is $2.5-4 \mathrm{~m}$ thick in the valley floor around $1200 \mathrm{~m}$ a.p.s.l. (King, 1984) and the fine soil is only rarely deeper than $1 \mathrm{~m}$, the amount of SOC stored in the permafrost layer is assumed to be negligible.

The vegetation and SOC distribution in Tarfala Valley allow some considerations about future total ecosystem $\mathrm{C}$ storage in the area under conditions of global climate change. Climate warming will result in an upwards shift of vegetation zones with the corresponding initiation of soil development in currently high-alpine barren areas. Upwards altitudinal

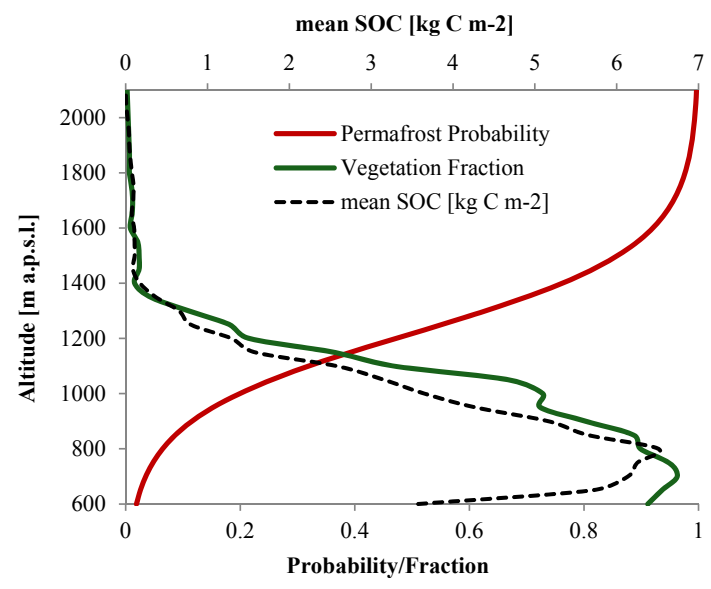

Figure 5. Fraction of vegetation cover and probability for permafrost presence in relation to altitude in Tarfala Valley, including the mean SOC storage per altitude (calculated in $50 \mathrm{~m}$ altitudinal intervals). The permafrost probability is based on the BTS measurements and a logistic regression with the altitude as single independent variable. The vegetation fraction is based on the altitudinal distribution of vegetated classes in the land cover classification. Slightly lower SOC values at elevations below $700 \mathrm{~m}$ are related to exposed streambeds in the Tarfala river alluvial fan.

shifts of plants due to increased temperatures have been observed in alpine regions (e.g., Walther et al., 2005), including the Scandinavian mountain range (e.g., Klanderud and Birks, 2003; Kullman, 2002, 2010). Kullman and Öberg (2009) report an altitudinal upward shift of trees of about $200 \mathrm{~m}$ in the past 100 years in the Swedish Scandes, in accordance with observed temperature increases. For a first rough estimation of potential upwards shifts of vegetation zones, the mean summer temperature change was taken as a first indicator even though many other factors will affect the vegetation (e.g., winter temperatures, precipitation, wind exposure; Kullman, 2010). The projected mean summer (JJA) temperature increase for the Tarfala mountain region until 2100 is $2.8^{\circ} \mathrm{C}$ (SRES A1B scenario, SMHI, 2013). Considering a summer lapse rate of $5.8^{\circ} \mathrm{C} \mathrm{km}^{-1}$ (Jonsell et al., 2013), the potential altitudinal upward shift for the vegetation cover is ca. 500 m. Grace et al. (2002) and Kullman (2010) calculated a similar potential treeline shift in the region by the end of this century. However, not the entire Tarfala Valley will be suitable for plant colonization, because of steep slopes, a lack of fine-soil matrix, and wind-exposed ridges.

Schuur et al. (2009) showed that in the Alaskan tundra, increased plant productivity is eventually outweighed by increased decomposition of deeper and older SOM following permafrost thaw. For projections of permafrost degradation in Tarfala Valley, the mean annual air temperature has to be considered. A climate scenario for the Tarfala mountain region estimates a mean annual temperature increase of ca. $4.6^{\circ} \mathrm{C}$ until 2100 (SRES A1B scenario, SMHI, 2013). Taking into account a mean annual lapse rate of $4.5^{\circ} \mathrm{C} \mathrm{km}^{-1}$ 
(Jonsell et al., 2013), the $0{ }^{\circ} \mathrm{C}$ air temperature isotherm could rise with ca. $1000 \mathrm{~m}$, which would greatly affect permafrost occurrence in the area. Data from the PACE borehole at Tarfalaryggen show that the permafrost temperature at the zero annual amplitude depth of $20 \mathrm{~m}$ has already experienced a warming of $0.047^{\circ} \mathrm{Cyr}^{-1}$ (Jonsell et al., 2013). Even though future permafrost degradation is highly plausible for most of the upper Tarfala Valley, only a negligible amount of SOC is currently stored in the area and could be affected by thaw. Under future climate warming and permafrost thawing, little or no SOC will be remobilized from permafrost soils in Tarfala Valley. On the contrary, increased temperatures will lead to an upward vegetation shift, phytomass production and soil development, with the result of an increased $\mathrm{C}$ uptake in Tarfala Valley in the future. The only way that projected permafrost thaw might negatively affect $\mathrm{C}$ uptake is through an initial increased slope instability in steep terrain (Gregory and Goudie, 2011; French, 2007), which could prevent vegetation establishment and soil development.

Compared to lowland permafrost regions in the northern circumpolar region (see e.g., Gruber et al., 2004; Zimov et al., 2006b; Schuur et al., 2009), a subarctic high-alpine permafrost environment like the upper Tarfala Valley cannot be considered a future source of $\mathrm{C}$ to the atmosphere. In general, alpine permafrost environments above the contiguous vegetation limit have the potential of becoming a $C$ sink in the future and therefore stand out as an exception in the general assessment of thawing permafrost soils representing an important positive feedback to future climate warming (e.g., Schuur et al., 2013).

\section{Conclusions}

The SOC inventory in Tarfala Valley, with a mean storage of $0.9 \mathrm{~kg} \mathrm{C} \mathrm{m}^{-2}$ for the upper meter of soil, shows that this area cannot be considered a C-rich permafrost environment. This low value is a result of the high amount of barren ground and stony surfaces in the study area, low plant productivity, shallow soils and lack of SOM burial through cryoturbation or slope processes. The low SOC storage leads to the conclusion that environments like Tarfala Valley cannot become significant sources of $\mathrm{C}$ with future permafrost thawing. Instead, they could act as net $\mathrm{C}$ sinks following an upward shift of vegetation zones causing increased phytomass production, soil development and SOM accumulation. The potential magnitude of an increased $\mathrm{C}$ uptake in this type of mountainous permafrost region remains to be addressed by further studies. Nevertheless, this study shows that there is a need to include alpine environments to estimate the total SOC stock in permafrost soils of the northern circumpolar region and to fully assess the permafrost thaw-C feedback.

The Supplement related to this article is available online at doi:10.5194/tc-9-427-2015-supplement.
Acknowledgements. We wish to thank Eva-Lisa and Juri Palmtag, Niels Weiss and Malin Brandel for help with the fieldwork, Andreas Bergström and his team for the support at Tarfala research station and two anonymous reviewers for their constructive comments. The study was supported by the Nordic Center of Excellence DEFROST project.

Edited by: P. Marsh

\section{References}

Bockheim, J. G.: Importance of cryoturbation in redistributing organic carbon in permafrost-affected soils, Soil Sci. Soc. Am. J., 71, 1335-1342, doi:10.2136/sssaj2006.0414N, 2007.

Bolin Centre for Climate Research: Bolin Centre Database, Tarfala data, permafrost monitoring data, http://bolin.su.se/data/tarfala/ permafrost.php, last access: 30 October 2013.

Bronk Ramsey, C.: OxCal v4.1.7, Radiocarbon Calibration Software, Research Lab for Archaeology, Oxford, UK, available at: http://c14.arch.ox.ac.uk (last access: 13 February 2013), 2010.

Brown, J., Ferrians Jr., O. J., Heginbottom, J. A., and Melnikov, E. S.: Circum-Arctic map of permafrost and ground-ice conditions, $1: 10000$ 000, Map CP-45, United States Geological Survey, International Permafrost Association, Washington, D.C., 1997.

Campbell, J. B.: Introduction to remote sensing, 5th Edn., Guilford Press, New York, 667 pp., 2011.

Dahlke, H. E., Lyon, S. W., Stedinger, J. R., Rosqvist, G., and Jansson, P.: Contrasting trends in floods for two sub-arctic catchments in northern Sweden - does glacier presence matter?, Hydrol. Earth Syst. Sci., 16, 2123-2141, doi:10.5194/hess-16-21232012, 2012.

Dean, W. E.: Determination of carbonate and organic matter in calcareous sediments and sedimentary rocks by loss on ignition: Comparison with other methods, J. Sediment. Petrol., 44, 242248, 1974.

Doerfer, C., Kuehn, P., Baumann, F., He, J.-S., and Sholten, T.: Soil organic carbon pools and stocks in permafrostaffected soils on the Tibetan Plateau, PLOS ONE, 8, e57024, doi:10.1371/journal.pone.0057024, 2013.

Dostmann Electronic: Temperature Probe P400, http: //www.dostmann-electronic.de/englisch/Produkte/produkt. php?pid=205\&lang=eng, last access: 6 May 2013.

European Space Imaging GMBH: WorldView2 satellite image, date of acquisition: 4 July 2012, http://www.euspaceimaging.com/ (last access: 6 May 2013), 2012.

French, H. M.: The Periglacial Environment, 3rd Edn., John Wiley \& Sons Ltd, West Sussex, England, 480 pp., doi:10.1002/9781118684931, 2007.

Grace, J., Berninger, F., and Nagy, L.: Impacts of climate change on tree line, Ann. Bot.-London, 90, 537-544, 2002.

Gregory, K. J. and Goudie, S. A.: The SAGE Handbook of Geomorphology, SAGE Publications Ltd, London, England, 648 pp., 2011.

Gruber, N., Friedlingstein, P., Field, C. B., Valentini, R., Heimann, M., Richey, J. E., Romero-Lankao, P., Schulze, D., and Chen, C. T. A.: The vulnerability of the carbon cycle in the $21^{\text {st }}$ century: An assessment of carbon-climate-human interactions, in: The Global Carbon Cycle: Integrating Humans, Climate, and 
the Natural World, edited by: Field, C. and Raupach, M., Island Press, Washington, D.C., 45-76, 2004.

Haeberli, W.: Die Basis-Temperatur der winterlichen Schneedecke als möglicher Indikator für die Verbreitung von Permafrost in den Alpen, Z. Gletscherk. Glaziol., 9, 221-227, 1973.

Hammer, Ø., Harper, D. A. T., and Ryan, P. D.: PAST: Paleontological statistics software package for education and data analysis, Palaeontol. Electron., 4, available at: http://palaeo-electronica. org/2001_1/past/issue101.htm (last access: 6 March 2013), 2001.

Harris, C., Haeberli, W., Vonder Muehll, D., and King, L.: Permafrost monitoring in the high mountains of Europe: the PACE project in its global context, Permafrost Periglac., 12, 3-11, doi:10.1002/ppp.337, 2001

Heiri, O., Lotter, A. F., and Lemcke, G.: Loss on ignition as a method for estimating organic and carbonate content in sediments: reproducibility and comparability of results, J. Paleolimnol., 25, 101-110, doi:10.1023/A:1008119611481, 2001.

Holmlund, P., Jansson, P., and Pettersson, R.: A re-analysis of the 58 year mass-balance record of Storglaciären, Sweden, Ann. Glaciol., 42, 389-394, 2005.

Horwath Burnham, J. and Sletten, R. S.: Spatial distribution of soil organic carbon in northwest Greenland and underestimates of high arctic carbon stores, Global Biogeochem. Cy., 24, GB3012, doi:10.1029/2009GB003660, 2010.

Hugelius, G.: Spatial upsacling using thematic maps: An analysis of uncertainties in permafrost soil carbon estimates, Global Biogeochem. Cy., 26, GB2026, doi:10.1029/2011GB004154, 2012.

Hugelius, G., Kuhry, P., Tarnocai, C., and Virtanen, T.: Soil organic carbon pools in a periglacial landscape: A case study from the central Canadian Arctic, Permafrost Periglac., 21, 16-29, doi:10.1002/ppp.677, 2010.

Hugelius, G., Virtanen, T., Kaverin, D., Pastukhov, A., Rivkin, F., Marchenko, S., Romanovsky, V., and Kuhry, P.: High-resolution mapping of ecosystem carbon storage and potential effects of permafrost thaw in periglacial terrain, European Russian Arctic, J. Geophys. Res., 116, G03024, doi:10.1029/2010JG001606, 2011.

Hugelius, G., Routh, J., Kuhry, P., and Crill, P.: Mapping the degree of decomposition and thaw remobilization potential of soil organic matter in discontinuous permafrost terrain, J. Geophys. Res., 117, G02030, doi:10.1029/2011JG001873, 2012.

Hugelius, G., Tarnocai, C., Broll, G., Canadell, J. G., Kuhry, P., and Swanson, D. K.: The Northern Circumpolar Soil Carbon Database: spatially distributed datasets of soil coverage and soil carbon storage in the northern permafrost regions, Earth Syst. Sci. Data, 5, 3-13, doi:10.5194/essd-5-3-2013, 2013.

Hugelius, G., Strauss, J., Zubrzycki, S., Harden, J. W., Schuur, E. A. G., Ping, C.-L., Schirrmeister, L., Grosse, G., Michaelson, G. J., Koven, C. D., O’Donnell, J. A., Elberling, B., Mishra, U., Camill, P., Yu, Z., Palmtag, J., and Kuhry, P.: Estimated stocks of circumpolar permafrost carbon with quantified uncertainty ranges and identified data gaps, Biogeosciences, 11, 6573-6593, doi:10.5194/bg-11-6573-2014, 2014.

Isaksen, K., Sollid, J. L., Holmlund, P., and Harris, C.: Recent warming of mountain permafrost in Svalbard and Scandinavia, J. Geophys. Res., 112, F02S04, doi:10.1029/2006JF000522, 2007.

IUSS Working Group WRB: World reference base for soil resources, 2nd Edn., World Soil Resources Reports 103, FAO, Rome, 143 pp., 2006.
Jansson, P. and Pettersson, R.: Spatial and temporal characteristics of a long mass balance record, Storglaciären, Sweden, Arct. Antarct. Alp. Res., 39, 432-437, 2007.

Jonsell, U., Hock, R., and Duguay, M.: Recent air and ground temperature increases at Tarfala Research Station, Sweden, Polar Res., 32, 19807, doi:10.3402/polar.v32i0.19807, 2013.

King, L.: High mountain permafrost in Scandinavia, Permafrost: Fourth international conference, Proceedings, Nat. Acad. Press, Washington, D.C., 612-617, 1983.

King, L.: Permafrost in Skandinavien, Untersuchungsergebnisse aus Lappland, Jotunheimen und Dovre/Rondane, Heidelberger Geographische Arbeiten 76, University of Heidelberg, Department of Geography, Heidelberg, 174 pp., 1984.

Klanderud, K. and Birks, H. J. B.: Recent increases in species richness and shifts in altitudinal distribution of Norwegian mountain plants, Holocene, 13, 1-6, 2003.

Kuhry, P. and Vitt, D. H.: Fossil carbon/nitrogen ratios as a measure of peat decomposition, Ecology, 77, 271-275, doi:10.2307/2265676, 1996.

Kuhry, P., Mazhitova, G. G., Forest, P.-A., Deneva, S. V., Virtanen, T., and Kultti, S.: Upscaling soil organic carbon estimates for the Usa Basin (Northeast European Russia) using GIS-based landcover and soil classification schemes, Dan. J. Geogr., 102, 11-25, 2002.

Kuhry, P., Dorrepaal, E., Hugelius, G., Schuur, E. A. G., and Tarnocai, C.: Potential remobilization of belowground permafrost carbon under future global warming, Permafrost Periglac., 21, 208-214, doi:10.1002/ppp.684, 2010.

Kullman, L.: Rapid recent range-margin rise of tree and shrub species in the Swedish Scandes, J. Ecol., 90, 68-77, 2002.

Kullman, L.: A richer, greener and smaller alpine world: review and projection of warming-induced plant cover change in the Swedish Scandes, Ambio, 39, 159-169, doi:10.1007/s13280010-0021-8, 2010.

Kullman, L. and Öberg, L.: Post-little ice age tree line rise and climate warming in the Swedish Scandes: a landscape ecological perspective, J. Ecol., 97, 415-429, doi:10.1111/j.13652745.2009.01488.x, 2009.

Lantmäteriet: CIR aerial images 08o48zu50_31 2008-0910_105654_98-08o48zu50_31_2008-09-10_105654_103, http://www.lantmateriet.se/ (last access: 6 May 2013), 2008.

Lewkowicz, A. G. and Ednie, M.: Probability mapping of mountain permafrost using the BTS Method, Wolf Creek, Yukon Territory, Canada, Permafrost Periglac., 15, 67-80, doi:10.1002/ppp.480, 2004.

Mariotti, A. and Balesdent, J.: ${ }^{13} \mathrm{C}$ natural abundance as a tracer of soil organic matter turnover and paleoenvironment dynamics, Chem. Geol., 84, 217-219, 1990.

Marklund, P.: Alpin permafrost i Kebnekaisefjällen: Modellering med logistic regression och BTS-data, Självständigt arbete i geovetenskap, Nr. 22, Uppsala University, Disciplinary Domain of Science and Technology, Earth Sciences, Department of Earth Sciences, LUVAL, Uppsala, 2011.

McGuire, A. D., Macdonald, R. W., Schuur, E. A. G., Harden, J. W., Kuhry, P., Hayes, D. J., Christensen, T. R., and Heimann, M.: The carbon budget of the northern cryosphere region, Curr. Opin. Environ. Sustain., 2, 231-236, 2010. 
Michaelson, G. J., Ping, C. L., and Kimble, J. M.: Carbon storage and distribution in tundra soils of Arctic Alaska, U.S.A., Arctic Alpine Res., 28, 414-424, 1996.

Mishra, U., Jastrow, J. D., Matamala, R., Hugelius, G., Koven, C. D., Harden, J. W., Ping, C. L., Michaelson, G. J., Fan, Z., Miller, R. M., McGuire, A. D., Tarnocai, C., Kuhry, P., Riley, W. J., Schaefer, K., Schuur, E. A. G., Jorgenson, M. T., and Hinzman, L. D.: Empirical estimates to reduce modelling uncertainties of soil organic carbon in permafrost regions: a review of recent progress and remaining challenges, Environ. Res. Lett., 8, 035020, doi:10.1088/1748-9326/8/3/035020, 2013.

Ohtsuka, T., Hirota, M., Zhang, X., Shimono, A., Senga, Y., Du, M., Yonemura, S., Kawashima, S., and Tang, Y.: Soil organic carbon pools in alpine to nival zones along an altitudinal gradient (4400$5300 \mathrm{~m}$ ) on the Tibetan Plateau, Polar Science, 2, 227-285, 2008.

Palmtag J., Hugelius, G., Lashchinskiy, N. Tamstorf, M. P., Richter, A., Elberling, B., and Kuhry, P.: Storage, landscape distribution, and burial history of soil organic matter in contrasting areas of continuous permafrost, Arct. Antart. Alp. Res., 47, 71-88, doi:10.1657/AAAR0014-027, 2015.

Ping, C. L., Bockheim, J. G., Kimble, J. M., Michaelson, G. J., and Walker, D. A.: Characteristics of cryogenic soils along a latitudinal transect in Arctic Alaska, J. Geophys. Res., 103, 2891728928, doi:10.1029/98JD02024, 1998.

Ping, C. L., Michaelson, G. J., Jorgenson, M. T., Kimble, J. M., Epstein, H., Romanovsky, V. E., and Walker, D. A.: High stocks of soil organic carbon in the North American arctic region, Nat. Geosci., 1, 615-619, doi:10.1038/ngeo284, 2008.

Schuur, E. A. G., Bockheim, J., Canadell, J. G., Euskirchen, E., Field, C. B., Goryachkin, S. V., Hagemann, S., Kuhry, P., Fafleur, P. M., Lee, H., Mazhitova, G., Nelson, F. E., Rinke, A., Romanovsky, V. E., Shiklomanov, N., Tarnocai, C., Venevsky, S., Vogel, J. G., and Zimov, S. A.: Vulnerability of permafrost carbon to climate change: Implications for the global carbon cycle, BioScience, 58, 701-714, doi:10.1641/B580807, 2008.

Schuur, E. A. G., Vogel, J. G., Crummer, K. G., Lee, H., Sickman, J. O., and Osterkamp, T. E.: The effect of permafrost thaw on old carbon release and net carbon exchange from tundra, Nature, 459, 556-559, doi:10.1038/nature08031, 2009.

Schuur, E. A. G., Abbott, B. W., Bowden, W. B., Brovkin, V., Camill, P., Canadell, J. G., Chanton, J. P., Chapin III, F. S., Christensen, T. R., Ciais, P., Crosby, B. T., Czimczik, C. I., Grosse, G., Harden, J., Hayes, D. J., Hugelius, G., Jastrow, J. D., Jones, J. B., Kleinen, T., Koven, C. D., Krinner, G., Kuhry, P., Lawrence, D. M., McGuire, A. D., Natali, S. M., O'Donnell, J. A., Ping, C. L., Riley, W. J., Rinke, A., Romanovsky, V. E., Sannel, A. B. K., Schädel, C., Schaefer, K., Sky, J., Subin, Z. M., Tarnocai, C., Turetsky, M. R., Waldrop, M. P., Walter Anthony, K. M., Wickland, K. P., Wilson, C. J., and Zimov, S. A.: Expert assessment of vulnerability of permafrost carbon to climate change, Climatic Change, 119, 359-374, doi:10.1007/s10584-013-0730-7, 2013.
SMHI, Sveriges meteorologiska och hydrologiska institut, Klimatscenarier: http://www.smhi.se/klimatdata/ Framtidens-klimat/Klimatscenarier/2.2252/2.2264 (last access: 8 November 2013), 2013.

Sollid, J. L., Holmlund, P., Isaksen, K., and Harris C.: Deep permafrost boreholes in western Svalbard, northern Sweden, and southern Norway, Norsk. Geogr. Tidsskr., 54, 186-191, 2000.

Stork, A.: Plant immigration in front of retreating glaciers, with examples from the Kebnekajse area, Northern Sweden, Geograf. Ann., 45, 1-22, 1963.

Tarnocai, C., Canadell, J. G., Mazhitova, G., Schuur, E. A. G., Kuhry, P., and Zimov, S.: Soil organic carbon pools in the northern circumpolar permafrost region, Global Biogeochem. Cy., 23, GB2023, doi:10.1029/2008GB003327, 2009.

US Geological Survey: Earth Resources Observation and Science Center (EROS), USGS Global Visualization Viewer, Landsat 5 TM satellite image, acquisition date: 18 September 2011, http://glovis.usgs.gov/ (last access: 25 October 2012), 2011.

Walker, M.: Quaternary dating methods, John Wiley \& Sons Ltd, England, 306 pp., 2005.

Walther, G.-R., Beissner, S., and Burga, C. A.: Trends in the upward shift of alpine plants, J. Veg. Sci., 16, 541-548, 2005.

Wang, G., Li, Y., Wang, Y., and Wu, Q.: Effects of permafrost warming on vegetation and soil carbon pool losses on the QinghaiTibet Plateau, China, Geoderma, 143, 143-152, 2008.

Yang, Y., Fang, J., Tang, Y., Ji, C., Zheng, C., He, J., and Zhu, B.: Storage, patterns and controls of soil organic carbon in the Tibetan grasslands, Global Change Biol., 14, 1592-1299, doi:10.1111/j.1365-2486.2008.01591.x, 2008.

Zimov, S. A., Schuur, E. A. G., and Chapin, F. S.: Permafrost and the global carbon budget, Science, 312, 1612-1613, doi:10.1126/science.1128908, 2006a.

Zimov, S. A., Davydov, S. P., Zimova, G. M., Davydova, A. I., Schuur, E. A. G., Dutta, K., and Chapin III, F. S.: Permafrost carbon: Stock and decomposability of a globally significant carbon pool, Geophys. Res. Lett., 33, L20502, doi:10.1029/2006GL027484, 2006b.

Zollinger, B., Alewell, C., Kneisel, C., Meusburger, K., Gärtner, H., Brandová, D., Ivy-Ochs, S., Schmidt, M. W. I., and Egli, M.: Effect of permafrost on the formation of soil organic carbon pools and their physical-chemical properties in the Eastern Swiss Alps, Catena, 11, 70-85, doi:10.1016/j.catena.2013.06.010, 2013. 